\title{
Glosa do wyroku Naczelnego Sądu Administracyjnego Z 31 SIERPNIA 2017 R., II OSK 3025/15, LEX NR 2390501
}

Przy ustalaniu kręgu stron postępowania administracyjnego w sprawach dotyczących wydania pozwolenia na budowę, nie jest decydujące, czy oddziaływanie inwestycji mieści się w określonych prawem normach, ale ustalenie, czy nieruchomość jest położona w strefie narażenia na różne immisje.

Glosowany wyrok zapadł w związku z zagadnieniem dotyczącym ustalenia statusu prawnego wnioskodawcy w sprawie wszczęcia postępowania administracyjnego o stwierdzenie nieważności decyzji administracyjnej odnoszącej się do wydanego pozwolenia na budowę.

W stanie faktycznym leżącym u podstaw komentowanego orzeczenia Naczelnego Sądu Administracyjnego, skarżący złożył wniosek o stwierdzenie nieważności decyzji starosty w sprawie pozwolenia na budowę elektrowni wiatrowej wraz z infrastrukturą techniczną, powołując się na swój interes prawny wyrażający się bezpośrednim sąsiedztwem planowanej inwestycji z nieruchomościami stanowiącymi jego własność. Wojewoda jednak odmówił wszczęcia postępowania administracyjnego w sprawie stwierdzenia nieważności decyzji starosty, z powodu braku udziału skarżącego w postępowaniu dotyczącym wydania pozwolenia na budowę. Organ po dokonaniu analizy projektu budowlanego zatwierdzonego decyzją starosty stwierdził, że skarżący nie posiada legitymacji procesowej do wszczęcia postępowania o stwierdzenie nieważności decyzji, ponieważ planowane przedsięwzięcie nie będzie oddziaływać na jego nieruchomości, w szczególności nie ograniczy sposobu ich zagospodarowania. Postanowienie to, utrzymał w mocy Główny Inspektor Nadzoru Budowlanego. Następnie wskutek wniesienia skargi przez właściciela nieruchomości, sprawę rozpoznał Wojewódzki Sąd

\footnotetext{
* Dr, Uniwersytet Rzeszowski; e-mail: sla_z@poczta.fm.
} 
Administracyjny. WSA stwierdził, że działki skarżącego znajdują się poza strefą techniczną elektrowni, wyznaczoną w obowiązującym planie miejscowym, a inwestycja nie przekracza norm dotyczących hałasu. Skarżący nie zgodził się z wyrokiem WSA i złożył skargę kasacyjną, którą NSA uwzględnił i przyznał skarżącemu legitymację procesową w postępowaniu w sprawie stwierdzenia nieważności decyzji o pozwoleniu na budowę.

Jak zauważył w swym orzeczeniu NSA, w kontekście zastosowania art. 61a § 1 k.p.a. ${ }^{1}$, dominujące jest stanowisko, że żądanie osoby nie wszczyna postępowania administracyjnego, tylko wówczas, gdy zostało zgłoszone przez podmiot oczy wiście nieuprawniony, tzn. gdy z podania w sposób oczywisty wynika, że wnoszący składa je nie w swojej sprawie, tj. nie wywodzi własnego interesu prawnego. W każdym innym przypadku organ administracji publicznej nie powinien odmawiać wszczęcia postępowania, ale kontynuować je i w jego trakcie ustalić status prawny wnioskodawcy. Tylko w toku postępowania organ, może dokonać niezbędnych ocen w zakresie norm prawa materialnego, odnoszących się do praw podmiotu wnoszącego żądanie, a w konsekwencji ustalić, czy podmiot ten ma interes prawny w sprawie. Załatwienie takiego żądania powinno nastąpić $\mathrm{w}$ drodze wydania decyzji. Jeżeli przeprowadzone postępowanie doprowadzi do ustalenia, że wnoszący podanie nie legitymuje się interesem prawnym, organ powinien na podstawie art. $105 \S 1$ k.p.a. postępowanie umorzyć ${ }^{2}$.

W świetle zaprezentowanego poglądu NSA, dodać trzeba, że w ramach spraw dotyczących stwierdzenia nieważności decyzji administracyjnej, kontynuowany jest kierunek orzeczniczy ukształtowany na tle art. 157 § 3 k.p.a., według którego odmowa wszczęcia postępowania powinna mieć miejsce w sytuacjach wyjątkowych, gdy nie ma wątpliwości co do przyczyn podmiotowych takiego rozstrzygnięcia. Akcentuje się przy tym, że wadliwe jest takie procedowanie, kiedy na etapie wstępnego badania wniosku organ administracji prowadzi postępowanie wyjaśniające, bez możliwości zagwarantowania wnioskodawcy udziału w czynnościach procesowych. Organ na etapie wstępnym nie ma uprawnienia do weryfikowania legitymacji procesowej wnioskodawcy w oparciu o zebrane

1 Ustawa z dnia 14 czerwca 1960 r. - Kodeks postępowania administracyjnego, Dz. U. z 2017 r. poz. 1257 (dalej k.p.a.).

2 Zob. wyrok Naczelnego Sądu Administracyjnego z 18 maja 2016 r., II OSK 2177/14, LEX nr 2108460; wyrok NSA z 5 lipca 2016 r., I OSK 2352/14, LEX nr 2100597; wyrok NSA z 18 listopada 2016 r., II OSK 330/15, LEX nr 2206606; wyrok NSA z 16 grudnia 2016 r., II OSK 600/14, LEX nr 2002207; wyrok NSA z 21 grudnia 2016 r., II OSK 1452/16, LEX nr 2205100; wyrok NSA z 24 stycznia 2017 r., II OSK 1060/15, LEX nr 2261563. 
w sprawie dowody w sytuacji, gdy jednocześnie wnioskodawca nie miał zapewnionego dostępu do materiału dowodowego i nie miał możliwości wypowiedzenia się co do okoliczności istotnych dla ustalenia jego interesu prawnego ${ }^{3}$.

Dla potrzeb analizy przedmiotowego wyroku NSA, na wstępie należy wyjaśnić, co należy rozumieć pod pojęciem obszaru oddziaływania obiektu budowlanego, bowiem właściwe odkodowanie znaczenia pojęcia „obszar oddziaływania obiektu budowlanego" będzie miało doniosłe znaczenie $\mathrm{w}$ analizie omawianego wyroku NSA. W świetle art. 3 pkt 20 ustawy z dnia 7 lipca 1994 r. Prawo budowlane ${ }^{4}$, obszarem oddziaływania obiektu jest teren wyznaczony w otoczeniu obiektu budowlanego na podstawie przepisów odrębnych, wprowadzających związane z tym obiektem ograniczenia w zagospodarowaniu, w tym zabudowy tego terenu. Powyższa definicja obszaru oddziaływania obiektu budowlanego sugeruje, iż jest to jeden z tzw. obszarów specjalnych - terenów, na których obowiązuje specjalny reżim prawny, służący realizacji określonych celów społecznych. Na taką interpretację wskazuje sformułowanie, iż jest to teren wyznaczony w otoczeniu obiektu budowlanego na podstawie przepisów odrębnych, czyli jest on w sposób formalny ustanowiony i istnieje w chwili wszczęcia postępowania administracyjnego ${ }^{5}$. $Z$ kolei przez określenie ograniczenia w zagospodarowaniu terenu ustawodawca wyraźnie ujął ograniczenie zabudowy na terenie wyznaczonym w otoczeniu obiektu budowlanego. Jak zauważa Z. Niewiadomski, brzmienie definicji legalnej obszaru oddziaływania obiektu, może powodować zagrożenie zbyt wąskiego interpretowania przepisów odrębnych ${ }^{6}$. W doktrynie podkreśla się, że definicja obszaru oddziaływania obiektu jest nieprecyzyjna i może budzić kontrowersje w praktyce ${ }^{7}$. Dlatego wydaje się, że pojęcie obszaru oddziaływania obiektu musi być doprecyzowane przy każdej inwestycji na podstawie cech indywidualnych obiektu oraz jego przeznaczenia w odniesieniu do przepisów odrębnych, na podstawie których można ustalić obszar wokół realizowanej inwestycji, który będzie wprowadzał związane z tym obiek-

\footnotetext{
3 Zob. wyrok Naczelnego Sądu Administracyjnego z 28 marca 2012 r., II GSK 321/11, LEX nr 1219017; wyrok NSA z 19 lipca 2012 r., II OSK 647/11, LEX nr 1392919; wyrok NSA z 15 listopada 2013 r., II GSK 5/12, LEX nr 1291297; wyrok NSA z 26 marca 2013 r., II GSK 27/12, LEX nr 1334134; wyrok NSA z 17 grudnia 2013 r., II OSK 1810/12, LEX nr 1530684; wyrok NSA z 25 lutego 2014 r., II OSK 2271/12, LEX nr 1483446.

4 Ustawa z dnia 7 lipca 1994 r. Prawo budowlane, Dz. U. z 2017 r. poz. 1332 z późn. zm. (dalej pr.bud.).

5 M. Laskowska, Ochrona interesów sąsiadów w procesie budowlanym po nowelizacji, „Samorząd Terytorialny" 2004, nr 5, s. 41.

6 Z. Niewiadomski [w:] Z. Niewiadomski (red.), Prawo budowlane. Komentarz, Warszawa 2006, s. 87.

7 J. Siegień, Prawo budowlane. Komentarz, Warszawa 2003, s. 206.
} 
tem budowlanym ograniczenia zagospodarowania tego terenu ${ }^{8}$. Wyznaczenie takiego obszaru powinno nastąpić na potrzeby każdej konkretnej sprawy i uwzględniać funkcję, formę, konstrukcję projektowanego obiektu i inne jego cechy charakterystyczne oraz sposób zagospodarowania terenu znajdującego się $\mathrm{w}$ otoczeniu projektowanej inwestycji budowlanej, przy czym nie muszą to być nieruchomości bezpośrednio sąsiadujące z nieruchomością objętą projektowaną inwestycją. Inaczej rzecz ujmując, pojęcie obszaru oddziaływania obiektu jest rekonstruowane w każdym postępowaniu prowadzonym dla indywidualnych inwestycji. Pamiętać należy, że obszar oddziaływania obiektu budowlanego wyznaczany jest na podstawie odrębnych przepisów, przez które należy rozumieć nie tylko przepisy rozporządzeń określających warunki techniczne, jakim powinny odpowiadać budynki i ich usytuowanie ${ }^{10}$, ale także przepisy z zakresu ochrony środowiska ${ }^{11}$, zagospodarowania przestrzennego ${ }^{12}$ oraz przepisy prawa cywilnego ${ }^{13} \mathrm{~W}$ zakresie ochrony prawa własności ${ }^{14}$. Ponadto przepisami odrębnymi mogą być także: przepisy z zakresu ochrony zabytków, ochrony przyrody, prawo wodne, prawo lotnicze, przepisy prawa miejscowego oraz stosowne przepisy wykonawcze do ustaw. A więc obszaru oddziaływania obiektu budowlanego nie można utożsamiać wyłącznie z zachowaniem przez inwestora wymogów określonych przepisami techniczno-budowlanymi, ponieważ obiekt budowlany może wprowadzać określone ograniczenie w zagospodarowaniu terenu, co nie oznacza, że jego realizacja jest niezgodna z tymi przepisami i skutkować brakiem uzyskania na jego realizację pozwolenia na budowę ${ }^{15}$. Zatem definicja za-

\footnotetext{
8 Wyrok Naczelnego Sądu Administracyjnego z 14 grudnia 2010 r., II OSK 1872/09, LEX nr 746836.

9 Wyrok Wojewódzki Sąd Administracyjny w Poznaniu z 7 grudnia 2010 r., II SA/Po 673/10, LEX nr 750065.

10 Obwieszczenie Ministra Infrastruktury i Rozwoju z dnia 17 lipca 2015 r. w sprawie ogłoszenia jednolitego tekstu rozporządzenia Ministra Infrastruktury w sprawie warunków technicznych, jakim powinny odpowiadać budynki i ich usytuowanie, Dz. U. z 2015 r. poz. 1422.

11 Ustawa z dnia 27 kwietnia 2001 r. Prawo ochrony środowiska, Dz. U. z 2018 r. poz. 799 z późn. zm.

12 Ustawa z dnia 27 marca 2003 r. o planowaniu i zagospodarowaniu przestrzennym, Dz. U. z 2017 r. poz. 1073 z późn. zm.

13 Ustawa z dnia 24 kwietnia 1964 r. Kodeks cywilny, Dz. U. z 2017 r. poz. 459 z późn. zm.

14 Wyrok Naczelnego Sądu Administracyjnego z 17 kwietnia 2014 r., II OSK 1899/13, LEX nr 1481894; wyrok NSA z 26 czerwca 2012 r., II OSK 1613/11, LEX nr 1217437; wyrok NSA z 8 czerwca 2011 r., II OSK 1296/10, LEX nr 1083596; wyrok NSA z 28 marca 2007 r., II OSK 208/06, LEX nr 340189.

${ }_{15}$ Zob. A. Plucińska-Filipowicz, A. Kosicki, Strony i sąsiedztwo w sprawach budowlanych, [w:] A. Plucińska-Filipowicz, M. Wierzbowski (red.), Proces inwestycji budowlanych, Warszawa 2015 , s. $49-50$.
} 
warta w art. 3 pkt 20 pr.bud. nie wyjaśnia jednak pojęcia obszaru oddziaływania obiektu budowlanego wprost, lecz zawiera odesłanie do licznych regulacji, wprowadzających szczegółowe wymogi dotyczące odległości w zabudowie i zagospodarowania terenu. W sytuacji, gdy wynikają z nich ograniczenia w zagospodarowaniu, a także w zabudowie sąsiednich nieruchomości, należy uznać, że dana nieruchomość znajduje się w obszarze oddziaływania zaplanowanego obiektu ${ }^{16}$. A zatem przez obszar oddziaływania obiektu budowlanego, należy rozumieć wyznaczony obszar ograniczonego użytkowania w postaci otuliny obszaru chronionego przez odrębne przepisy.

Z glosowanego wyroku NSA wynika, że ocena wpływu konkretnej inwestycji na sąsiedni obszar obejmuje szereg zagadnień związanych z oddziaływaniem projektowanego obiektu na znajdujące się w sąsiedztwie nieruchomości. Analizując oddziaływanie oznaczonej inwestycji w aspekcie interesu prawnego właścicieli nieruchomości pobliskich, organ administracji publicznej nie może ograniczać się tylko do ustalenia takiego oddziaływania, które stanowi naruszenie określonych norm. Zdaniem NSA, jeśli nieruchomości potencjalnie mogą być narażone na immisje, właściciel powinien uzyskać status strony, aby móc brać udział w postępowaniu dowodowym służącym zbadaniu, czy obowiązujące normy nie zostaną przekroczone w związku z realizacją przedsięwzięcia. Kwestia wielkości normatywnych lub nadnormatywnych określonych immisji ma więc znaczenie merytorycznego rozstrzygnięcia sprawy. Jak podkreśla się w literaturze, podstawową normą korzystania przez właściciela z nieruchomości, powinno być powstrzymanie się od działań zakłócających korzystanie z nieruchomości sąsiednich ponad przeciętną miarę określaną przez społeczno-gospodarcze przeznaczenie nieruchomości i stosunki miejscowe ${ }^{17}$.

NSA trafnie zauważył, że przy wyznaczeniu obszaru oddziaływania konkretnej inwestycji należy uwzględnić przepisy rozporządzeń określających warunki techniczne, jakim powinny odpowiadać budynki i ich usytuowanie, ale także przepisy z zakresu ochrony środowiska, zagospodarowania przestrzennego oraz przepisy prawa cywilnego w zakresie ochrony prawa własności. Inwestor, który pierwszy zabuduje swoją działkę, nie ma tylko z tego tytułu dodatkowych, większych uprawnień. Przy ustalaniu kręgu stron w sprawie pozwolenia na budowę uwzględnić należy wszelkie oddziaływanie na nieruchomości sąsiednie, które w świetle prawa powszechnie obowiązującego może oznaczać ograniczenie właścicieli w realizacji uprawnień związanych z zagospodarowaniem czy wyko-

\footnotetext{
16 Zob. R. Dziwiński, Komentarz do zmian w prawie budowlanym, „Gazeta Prawna” 2003, nr 95, s. 3.

17 Zob. S. Rudnicki, Własność nieruchomości, Warszawa 2008, s. 92.
} 
rzystaniem gruntów, do których przysługuje im tytuł prawny. Jeżeli bowiem dana nieruchomość znajdzie się w obszarze oddziaływania obiektu, to z mocy art. 28 ust. 2 pr.bud. jej właścicielowi, użytkownikowi wieczystemu lub zarządcy będzie przysługiwał status strony tego postępowania, obok samego inwestora.

Należy podkreślić, że w procesie inwestycyjno-budowlanym kwestia strony została uregulowana w sposób zróżnicowany w zależności od etapu procesu. Ustawodawca korzysta zarówno z regulacji kodeksowej art. 28 k.p.a., jak również wprowadza własne rozwiązania, które mają na celu ograniczenie liczby podmiotów biorących udział w postępowaniach związanych z projektowaniem, budową, utrzymaniem i rozbiórką obiektu budowlanego. W zamyśle ustawodawcy leży w ten sposób uproszczenie i przyspieszenie procesu budowlanego ${ }^{18}$. Mając na uwadze pojęcie obszaru oddziaływania obiektu budowlanego, ustawodawca ogranicza strony postępowania w sprawie pozwolenia na budowę do inwestora, użytkowników wieczystych i zarządców nieruchomości znajdujących się w tym obszarze $^{19}$. Owo ograniczenie polega na wskazaniu kategorii podmiotów uprawnionych do bycia stroną postępowania oraz na zdefiniowaniu pojęcia obszaru oddziaływania obiektu, które w założeniu ma ułatwić ustalenie interesu prawnego właściciela, użytkownika wieczystego oraz zarządcy sąsiednich nieruchomości ${ }^{20}$. Ustalając legitymację strony, ustawodawca w art. 28 ust. 2 pr.bud., w prowadza ograniczenia podmiotowe oraz przedmiotowe w stosunku do podmiotów, które spełniają kryteria określone $\mathrm{w}$ art. 28 k.p.a. Kryteria podmiotowe ograniczają legitymacje strony do inwestora, właściciela oraz użytkownika wieczystego nieruchomości. Kryterium przedmiotowe polega na wymogu znajdowania się nieruchomości w obszarze oddziaływania obiektu ${ }^{21}$.

W orzecznictwie i w doktrynie, zawężanie stron w postępowaniu dotyczącym pozwolenia na budowę, stanowi wyjątek od ogólnej zasady wyrażo-

18 Zdaniem E. Radziszewskiego, „naiwny jest pogląd, że zmniejszenie liczby uczestników, zakwalifikowanych jako strony, zmniejszy liczbę odwołań i skarg do organów administracji publicznej. Jak zauważa, taki punkt widzenia jest sprzeczny z zasadą art. 2 Konstytucji RP (Dz. U. Nr 78, poz. 483 z późn. zm.), że Rzeczpospolita Polska jest demokratycznym państwem prawnym, urzeczywistniającym zasady sprawiedliwości społecznej, a także z zasadą art. 42 Konstytucji RP, mówiącą o prawie do równego traktowania przez władze publiczne oraz zasadą art. 77 Konstytucji RP, przyznającą każdemu prawo do wynagrodzenia szkody, jaka została mu wyrządzona przez niezgodne z prawem działania organu władzy publicznej, a także zakazującą zamykania drogi sądowej dochodzenia naruszonych praw lub wolności", E. Radziszewski, Prawo budowlane. Przepisy i komentarz, Warszawa 2005 , s. 71.

19 Zob. J. Borkowski, Glosa do wyroku WSA z dnia 19 października 2004 r., II SA/Lu 161/04, „Orzecznictwo Sądów Polskich” 2006, nr 2, s. 16.

20 T. Moll, Przymiot strony w postępowaniu w sprawie pozwolenia na budowe, „Przegląd Prawa Publicznego" 2014, nr 9, s. 67.

21 Zob. S. Serafin, Prawo budowlane. Komentarz, Warszawa 2006, s. 269. 
nej w art. 28 k.p.a., zgodnie z którą stroną jest każdy, czyjego interesu prawnego dotyczy postępowanie albo kto żąda czynności organu ze względu na swój interes prawny lub obowiązek. A więc art. 28 ust. 2 pr.bud. jest niewattpliwie lex specialis w stosunku do przepisu art. 28 k.p.a. ${ }^{22}$ Ustawodawca wyłączył także działanie przepisu art. 31 k.p.a., wskutek czego organizacje społeczne zostały pozbawione prawa uczestnictwa $\mathrm{w}$ tym postępowaniu na prawach strony ${ }^{23}$. Organizacje te nie mogą więc korzystać z uprawnień przewidzianych przez art. 31 k.p.a., nie mogą również skutecznie zaskarżyć do sądu administracyjnego decyzji i postanowień zapadłych w tego rodzaju sprawach ${ }^{24}$. Istniejące wyjątki przewidziane w art. 28 ust. 2 pr.bud. nie powodują całkowitego wyłączenia stosowania art. 28 k.p.a. w zakresie ustalania stron postępowania w sprawie pozwolenia na budowę, gdyż przymiot strony nadal jest powiązany $\mathrm{z}$ istnieniem interesu prawnego lub obowiązku określonego podmiotu ${ }^{25}$.

W orzecznictwie sądowym podkreśla się wyraźnie, że obszar oddziaływania obiektu to nie tylko teren, w którym można odczuć skutki i uciążliwości spowodowane funkcjonowaniem danego obiektu. Nie można bowiem oddziaływania faktycznego utożsamiać z oddziaływaniem polegającym na wprowadzeniu ograniczeń prawnych. Tylko osoby, których prawo doznaje ograniczeń ze względu na realizację jakiegoś obiektu, posiadają interes prawny i są stronami postępowania o pozwolenie na budowę dla danego obiektu ${ }^{26}$.

${ }^{22}$ Odmienne zdanie w tej kwestii przedstawia W. Szwajdler. Jego zdaniem zakładając nawet dopuszczalność odrębnych niż w k.p.a. unormowań proceduralnych, należy zwrócić uwagę na możliwość stosowania przez analogię przepisów k.p.a., również w przypadku norm procesowych. Ponadto, należy zwrócić uwagę na uchwałę składu siedmiu sędziów SN z 8 czerwca 1995 r. (III AZP 9/95 OSNAPiUS 1995, nr 20, poz. 243.), która podkreśla, iż zasada praworządności przemawia za zachowaniem jednolitego porządku prawnego w sprawach niewymagających odmiennych regulacji prawnych. Ciekawostką jest także fakt, że w jednym z orzeczeń, NSA przyjął stanowisko o bezwzględnym prymacie k.p.a. nad przepisami szczególnymi, nawet wbrew tym przepisom. Zob. W. Szwajdler, Glosa do wyroku NSA z dnia 28 marca 2007 r., II OSK 208/06, "Orzecznictwo Sądów Polskich" 2008, nr 3, poz. 35.

${ }_{23}$ Zob. R. Dziwiński, P. Ziemski, Prawo budowlane. Komentarz, Warszawa 2006, s. 124; W. Chróścielewski, Strony i uczestnicy postępowania sadowoadministracyjnego, „Państwo i Prawo" 2004, nr 9, s. 34.

${ }_{24}$ Zob. D. Sypniewski, Deregulacja procesu inwestycyjno-budowlanego. Ograniczenie reglamentacji robót budowlanych, "Przegląd Prawa Publicznego” 2013, nr 2, s. 69.

25 Zob. A. Plucińska-Filipowicz, A. Kosicki, Strony i sasiedztwo..., s. 49; W sprawach z zakresu administracji publicznej dotyczących np. prawa budowlanego, gminie przymiot strony nie przysługuje, jedynie wyjątkowo, gdy zakres rozstrzygnięcia obejmuje sferę interesu prawnego gminy, przysługuje jej status strony. Wyrok NSA z 15 listopada 2000 r., IV SA 1164/98, LEX nr 53387.

26 Wyrok WSA w Poznaniu z 24 stycznia 2013 r., IV SA/Po 1092/12, LEX nr 1274834; Warto zauważyć odmienne od komentowanego wyroku stanowisko NSA wyrażone w wyroku 
Należy zauważyć, że sąsiedztwo nieruchomości względem nieruchomości, na której ma być realizowana inwestycja, nie oznacza, iż zostaną one objęte automatycznie obszarem oddziaływania obiektu. Nie można bowiem postawić znaku równości pomiędzy "sąsiedztwem” a "obszarem oddziaływaniu obiektu”, który dopiero warunkuje przyznanie statusu strony $\mathrm{w}$ postępowaniu budowlanym ${ }^{27}$. Zatem, jeżeli nieruchomość sąsiednia znajduje się $\mathrm{w}$ obszarze oddziaływania obiektu zdefiniowanego w art. 3 pkt 20 pr.bud., właścicielowi tej nieruchomości, jej użytkownikowi wieczystemu czy też zarządcy przysługuje status strony w postępowaniu w sprawie pozwolenia na budowę danego obiektu ${ }^{28}$. Sama potencjalna, teoretyczna możliwość ograniczeń w sposobie zagospodarowania działki wskutek powstania w sąsiedztwie obiektu budowlanego, bez potrzeby konkretyzowania danego ograniczenia i realności jego powstania, nie wystarcza do zaliczenia jej w obręb oddziaływania inwestycji ${ }^{29}$. Wynika $\mathrm{z}$ tego, że kreślenie w sposób prawidłowy obszaru oddziaływania obiektu odgrywa także istotną rolę $\mathrm{w}$ odniesieniu do wymogu uzyskania pozwolenia na budowę obiektu budowlanego. Ponadto, jak zauważa w swym wyroku NSA, zadaniem organu administracji publicznej jest każdorazowo takie wyważenie interesu stron, aby inwestycja była realizowana w sposób nienaruszający uzasadnionego interesu właściciela działki sąsiedniej, ale z zachowaniem uprawnień inwestora.

Przeprowadzone rozważania dotyczące komentowanego wyroku NSA, pozwalają stwierdzić, że żądający wszczęcia postępowania administracyjnego w sprawie stwierdzenia nieważności decyzji musi mieć przymiot strony postępowania. Stronami postępowania w sprawach o unieważnienie decyzji dotyczących pozwolenia na budowę są wyłącznie inwestor oraz

z 28 kwietnia 2009 r., iż nawet fakt tzw. immisji pośrednich z jednej nieruchomości na inne nie uzasadnia przyznania poszkodowanej tymi niekorzystnymi oddziaływaniami osobie przymiotu strony w rozumieniu art. 28 ust. 2 pr.bud., II OSK 12/08, LEX nr 554936.

27 Wyrok WSA w Białymstoku z 20 listopada 2012 r., II SA/Bk 497/12, LEX nr 1248694; wyrok WSA w Gliwicach z 29 października 2015 r., II SA/Gl 413/15, LEX nr 1926644; wyrok NSA z 12 marca 2015 r., II OSK 2089/13, LEX nr 1675933.

28 Warto zauważyć stanowisko S. Rudnickiego, który stwierdza, że „sąsiednią nieruchomością jest nieruchomość znajdująca się w zasięgu zakłóceń pochodzących z nieruchomości wyjściowej, a nie tylko pozostającej bezpośrednio z nią w styczności", S. Rudnicki, Własność..., s. 92.

29 Wyrok Wojewódzkiego Sądu Administracyjnego w Warszawie z 4 lutego 2015 r., VIII SA/ Wa 507/14, LEX nr 1650210. W orzecznictwie sądowym zdarzają się również stanowiska odmienne, zgodnie z którymi nieruchomości sąsiednie znajdują się automatycznie w obszarze oddziaływania obiektu w rozumieniu ustawowej definicji wynikającej z art. 3 pkt 20 pr.bud., ponieważ sposób ich zagospodarowania jest uzależniony od powstałego na sąsiedniej działce obiektu budowlanego. Wyrok WSA w Gdańsku z 18 listopada 2015 r., II SA/Gd 427/15, LEX nr 1948846. 
właściciele, użytkownicy wieczyści lub zarządcy nieruchomości znajdujących się na obszarze oddziaływania obiektu. Obszar oddziaływania obiektu to teren wyznaczony w otoczeniu obiektu budowlanego na podstawie przepisów odrębnych, wprowadzających związane z tym obiektem ograniczenia w zagospodarowaniu tego terenu. Innymi słowy, podmiot, dla którego z przepisów prawa materialnego nie wynikają żadne uprawnienia ani obowiązki w związku z zatwierdzoną inwestycją, nie jest stroną postępowania w sprawie pozwolenia na budowę.

Należy zgodzić się z poglądem wyrażonym w orzeczeniu NSA, że zazwyczaj ustalenie kręgu stron uprawnionych do złożenia wniosku o stwierdzenie nieważności decyzji, nie może być potraktowane jako swoista kontrola formalnoprawna wniosku. Dlatego właściwe wydaje się, stanowisko NSA, że przeprowadzenie takiej kontroli wymaga analizy szeregu przepisów prawa, w oparciu o materiał dowodowy zgromadzony w aktach sprawy, bowiem zainteresowany rozstrzygnięciem wnioskodawca powinien mieć możliwość wypowiedzenia się co do zebranego materiału. Zagwarantowanie udziału wnioskodawcy, przez przeprowadzenie postępowania wyjaśniającego, jest szansą wyjaśnienia istotnych okoliczności niezbędnych do określenia wpływu danej inwestycji na nieruchomości skarżącego. Równocześnie warto zauważyć, że przesunięcie momentu, w którym organ administracji publicznej zdecyduje o podstawie do występowania podmiotu domagającego się stwierdzenia nieważności decyzji z etapu kontroli formalnoprawnej do merytorycznego rozpoznania sprawy, nie powinno oznaczać, że za strony postępowania będą uznawane podmioty legitymujące się wyłącznie interesem faktycznym. Oddziaływanie faktyczne, rozumiane jako uciążliwość w korzystaniu z prawa własności nieruchomości, nie stanowi bowiem prawnego ograniczenia w sposobie zagospodarowania nieruchomości znajdującej się w obszarze oddziaływania obiektu, które warunkuje przyznanie statusu strony. O tym, kto jest stroną postępowania, nie decyduje również subiektywne odczucie danego podmiotu, gdyż interes prawny musi istnieć obiektywnie i wiązać się z takimi ograniczeniami w zagospodarowaniu jego nieruchomości, które w powiązaniu z konkretnym przepisem prawnym przyznają mu przymiot, o którym mowa w art. 28 ust. 2 pr.bud. Tylko takie podejście daje gwarancję, że instytucja stwierdzenia nieważności decyzji nie będzie wykorzystywana instrumentalnie $\mathrm{w}$ różnego rodzaju sporach $\mathrm{z}$ inwestorem realizującym określone przedsięwzięcie.

Słowa kluczowe: prawo budowlane, obszar oddziaływania obiektu budowlanego, strona postępowania 


\section{Bibliografia}

Borkowski J., Glosa do wyroku WSA z dnia 19 października 2004 r., II SA/Lu 161/04, „Orzecznictwo Sądów Polskich” 2006, nr 2, s. 14-21.

Chróścielewski W., Strony i uczestnicy postępowania sąowoadministracyjnego, „Państwo i Prawo" 2004, nr 9, s. 32-45.

Dziwiński R., Komentarz do zmian w prawie budowlanym, "Gazeta Prawna” 2003, nr 95, s. 3.

Dziwiński R., P. Ziemski, Prawo budowlane. Komentarz, Warszawa 2006.

Kostka Z., Prawo budowlane. Komentarz, Gdańsk 2005.

Laskowska M., Ochrona interesów sąsiadów w procesie budowlanym po nowelizacji, „Samorząd Terytorialny" 2004, nr 5, s. 37-49.

Moll T., Przymiot strony w postepowaniu w sprawie pozwolenia na budowe, "Przegląd Prawa Publicznego" 2014, nr 9, s. 66-75.

Niewiadomski Z. [w:] Z. Niewiadomski (red.), Prawo budowlane. Komentarz, Warszawa 2006, s. 3-166.

Plucińska-Filipowicz A., A. Kosicki, Strony i sasiedztwo w sprawach budowlanych, [w:] A. Plucińska-Filipowicz, M. Wierzbowski (red.), Proces inwestycji budowlanych, Warszawa 2015, s. 48-67.

Radziszewski E., Prawo budowlane. Przepisy i komentarz, Warszawa 2005.

Rudnicki S., Własność nieruchomości, Warszawa 2008.

Serafin S., Prawo budowlane. Komentarz, Warszawa 2006.

Siegień J., Prawo budowlane. Komentarz, Warszawa 2003.

Sypniewski D., Deregulacja procesu inwestycyjno-budowlanego. Ograniczenie reglamentacji robót budowlanych, "Przegląd Prawa Publicznego” 2013, nr 2, s. 67-79.

Szwajdler W., Glosa do wyroku NSA z dnia 28 marca 2007 r., II OSK 208/06, „Orzecznictwo Sądów Polskich" 2008, nr 3, s. 29-37.

\section{GLOSS ON SUPREME ADMNISTRATIVE COURT JUDGMENT OF 31 AUGUST 2017, II OSK 3025/15, LEX 2390501}

\section{$S \mathbf{u m ~ m}$ a r y}

The gloss is concerns the judgment of the Supreme Administrative Court of 31 August 2017 (II OSK 3025/15), which states that when determining the circle of parties to administrative proceedings in matters related to the issue of a building permit, any influence on neighboring properties should be taken into consideration generally applicable laws may mean limiting the owners in the exercise of their rights. In the light of the Supreme Administrative Court's judgment, the parties to the proceedings should be preceded by an analysis 
of many provisions, including the provisions of the Civil Code, if the property is exposed to immissions.

Key words: construction law, area of influence of a object building, party to the proceedings

\section{АНАДИЗ ПРИГОВОРА ГДАВНОГО АДМИНИСТРАТИВНОГО СУДА ОТ 31 АВГУСТА 2017 Г., II OS K 3025/15, LEX № 2390501}

$$
\text { P е } 3 \text { го м е }
$$

Анадиз касается приговора Высшего Административного Суда от 31 августа 2017 (II OSK 3025/15), который содержит, что при определении объема сторон административных производств в делах, касающихся разрешения на строение, следует взвесить все возможные воздействия на соседнюю недвижимость, которая в свете общеобязательного права может значить ограничение владельцев в выполнении их прав. На основании вынесения решения Высшего Административного Суда, определение сторон производства должно предшествовать анадизе многих положений, включая положений Гражданского кодекса, если недвижимость подвергана на нарушении правил добрососедства.

Ключевые слова: строительное право, воздействие пространства строительного объекта, сторона процесса 